\section{PEMBINAAN DAN PENINGKATAN MUTU MADRASAH DITINJAU DARI UNDANG-UNDANG SISTEM PENDIDIKAN NASIONAL}

\author{
Yundri Akhyar \\ Staf Kantor Kementerian Agama Kota Pekanbaru
}

\section{Abstract}

Training and Improving the Quality of Madrasah in Terms of Legislation of the National Education System: if it is reviewed. From the law number 20 in 2003 concerning the education system, madrasah is listed as an integral part of the national education system. Thus, the madrasah has the same rights and obligations with the school. But many people are still not satisfied with the management of madrasah education that exist today. That is because in the management of madrasah education has not been realized what is mandated by law on the National Education System, so there are still many problems that need to be addressed immediately. Legislation above provides opportunities, freedom and authority for local government to regulate and manage the madrasah education in the region including switch function in overseeing the madrasah committee. So that, madrasah education institutions are likely to be qualified and have high competitiveness.

Keywords: the education system, the quality of education, education.

\section{Pendahuluan}

Madrasah secara harfiah berasal dari Bahasa Arab yang artinya sama atau setara dengan kata Indonesia "sekolah" (school). ${ }^{1}$ Secara harfiyah madrasah bisa diartikan dengan sekolah, karena secara teknis keduanya memiliki kesamaan, yaitu sebagai tempat berlangsungnya proses belajar-mengajar secara formal. Namun demikian Karel Steenbrink membedakan madrasah dan sekolah karena keduanya mempunyai ciri khas yang berbeda. Madrasah memilki kurikulum,

${ }^{1}$ Depag RI, Pendidikan Islam dan Pendidikan Nasional, Paradigma Baru (Jakarta: Dirjen Agama Islam, 2005), hlm. 62

18 metode dan cara mengajar sendiri yang berbeda dengan sekolah. Madrasah sangat menonjol nilai religiulitas masyarakatnya. Sementara sekolah merupakan lembaga pendidikan umum dengan pelajaran universal dan terpengaruh iklim pencerahan Barat.

Madrasah dalam bentuk yang kita kenal saat ini memiliki konotasi spesifik, di mana anak memperoleh pembelajaran agama. Madrasah inilah yang tadinya disebut pendidikan keagamaan dalam bentuk belajar mengaji Al-Qur'an, kemudian ditambah dengan pelajaran ibadah praktis, terus ke pengajaran tauhid, hadis, tafsir, tarik Islam dan Bahasa Arab. Kemudian masuk pula pelajaran umum dan keterampilan. Dari segi jenjang pendidikan, mulanya madrasah identik dengan belajar mengaji Qur'an, jenjang pengajian tingkat dasar dan pengajian kitab tingkat lanjut, kemudian berubah ke jenjang Madrasah Ibtidaiyah, Madrasah Tsanawiyah, dan Madrasah Aliyah.

Tujuan pendirian madrasah pertama kalinya di Indonesia ialah untuk mentransmisikan nilai-nilai Islam, selain untuk memenuhi kebutuhan modernisasi pendidikan. Juga untuk mencegah memudarnya semangat keagamaan penduduk akibat meluasnya lembaga pendidikan belanda. Sekolah untuk pertama kalinya diperkenalkan oleh pemerintah Belanda pada sekitar dasawarsa 1870an bertujuan untuk menyiapkan calon pegawai pemerintah colonial, dengan maksud untuk melestarikan penjajahan. Dalam lembaga pendidikan yang didirikan Kolonial Belanda itu, tidak diberikan pelajaran agama sama sekali. Karena itu tidak heran jika di kalangan kaum pribumi, muncul resistensi yang kuat terhadap sekolah, yang mereka pandang sebagai bagian integral dari rencana pemerintah colonial Belanda. ${ }^{2}$ Pendidikan awal yang menjadi basis perjuangan rakyat dalam melawan penjajah adalah pesantren. Pesantren merupakan upaya kalangan pribumi untuk mengembangkan sistem pendidikan sendiri yang sesuai dengan tututan agama dan kebudayaan daerah untuk melindungi diri dari pengaruh pendidikan Belanda.

${ }^{2}$ Ibid., hlm. 48 
Namun, meskipun pesantren berperan lebih dahulu dalam membendung pengaruh pendidikan colonial (Belanda), dibandingkan dengan madrasah, para pembaharu pendidikan Islam di Indonesia tampaknya mengakui bahwa dalam banyak hal, lembaga pendidikan Islam tradisional ini mengandung banyak kelemahan, sementara disisi lain lembaga pendidikan yang didirikan pemerintah colonial Belanda harus diakui memiliki banyak kelebihan.

Madrasah yang didirikan di Indonesia tidak hanya untuk mengajarkan ilmu pengetahuan dan nilai-nilai Islam, tetapi juga memasukkan pelajaran yang diajarkan di sekolah-sekolah yang diselenggarakan pemerintah Hindia Belanda, seperti madrasah Adabiyah di Sumatera Barat, dan madrasah yang diselenggarakan oleh Muhammadiyah, Persatuan Islam, dan PUI di Majalengka. ${ }^{3}$

Misi penjajahan Belanda tidak hanya dilakukan lewat ekonomi tetapi juga dilakukan lewat pendekatan pendidikan. Lembaga pendidikan dianggap sebagai sarana yang paling efektif baik jangka pendek maupun jangka panjang. Madrasah yang seperti kebanyakan lembaga pendidikan modern lainnya, masuk pada sistem pendidikan di Indonesia pada awal abad ke 20-an, ini dimaksudkan sebagai upaya menggabungkan hal-hal yang fositif dari pendidikan pesantren dan sekolah. ${ }^{4}$

Setelah Belanda angkat kaki dari bumi Indonesia, maka muncul pergerakana Jepang. Jepang tidak begitu ketatnya terhadap pendidikan madrasah, kesetaraan pendidikan penduduk pribumi, sama dengan penduduk atau anak penguasa, bahkan Jepang banyak mengajarkan ilmu-ilmu bela diri kepada pemuda Indonesia. Pada masa penjajahan Jepang banyak berdirinya lembaga-lembaga pendidikan Islam

3 Samsul Nizar (Editor), Sejarah Pendidikan Islam: Menelusuri Jejak Sejarah Pendidikan Era Rasulullab Sampai Indonesia, (Jakarta: Kencana, 2008) hlm. 201

4 Abuddin Nata, Sejarah Pendidikan Islam, (Jakarta: RajaGrafindo Persada, 2004), hlm. 31 termasuk madrasah tempat anak-anak belajar agama dan mengaji. ${ }^{5}$

Masa Jepang, pendidikan agama Islam ditangani secara khusus. Pemerintah Jepang membaut relasi-positif dengan kiai dan ustadz, yang kemudian membuat kantor urusan agama (shumubu). Setelah tahun 1945-tepatnya tanggal 3 Januari 1946- kantor ini menjadi kementrian agama. Dalam tahun-tahun pertama, kementrian agama membuat divisi khusus yang menangani pendidikan agama di sekolah umum dan pendidikan agama di sekolah agama (madrasah dan pesantren). ${ }^{6}$

Lembaga pendidikan madrasah ini secara berangsur-angsur diterima sebagai salah satu institusi pendidikan Islam yang juga berperan dalam perkembangan peningkatan mutu pendidikan di Indonesia. ${ }^{7}$

Dari keterangan di atas menarik untuk dicatat bahwa salah satu karakteristik madrasah yang cukup penting di Indonesia pada awal pertumbuhannya ialah bahwa di dalamnya tidak ada komplik atau upaya mempertentangkan ilmu-ilmu agama dengan ilmu-ilmu umum. Komplik hanya biasa terjadi antara satu organisasi keagamaan dengan organisasi keagamaan lain yang memiliki faham keagamaan yang berbeda, dan mereka sama-sama mendirikan madrasah, misalnya NU, Muhammadiyah, Persis dan lain-lain, memiliki madrasahnya sendirisendiri untuk mensosialisasikan dan mengembangkan faham keagamaan mereka masing-masing.

Madrasah di Indonesia secara historis memiliki karakter yang sangat merakyat. Sesui dengan historis bahwa kebanyakan madrasah di Indonesia pada mulanya tumbuh dan berkembang atas inisiatif tokoh masyarakat yang peduli, terutama para ulama yang membawa gagasan

\section{${ }^{5}$ Ibid.}

${ }^{6}$ Zuhairini, dkk, Sejarah Pendidikan Islam, (Jakarta: Bumi Aksara, 1997) hlm. 45 hlm. 6

${ }^{7}$ Depag RI, Desain Pengembangan Madrasah (Jakarta: Dirjen Binbaga, 2004) 
pembaharuan pendidikan, setelah mereka kembali dari menuntut ilmu di Timur Tengah. Dana pembangunan dan pendidikannya pun berasal dari swadaya masyarakat. Karena inisiatif dan dananya didukung oleh masyarakat, maka masyarakat sendiri diuntungkan secara ekonomis, artinya mereka dapat memasukkan anak-anak mereka ke madrasah dengan biaya ringan. ${ }^{8}$

Menurut A. Malik Fadjar, sebagai lembaga pendidikan swadaya, madrasah menampung aspirasi sosial-budaya-agama masyarakat yang tinggal diwilayah pedesaan. Tumbuh dan berkembangnya madrasah di pedesaan itu menjadi petunjuk bahwa masyarakat Indonesia ternyata memiliki komitmen yang sangat tinggi terhadap pendidikan putra-putri mereka. ${ }^{9}$

Kini madrasah dipahami sebagai lembaga pendidikan Islam yang berada di bawah sistem pendidikan nasional dan di bawah pembinaan Departemen Agama. Lembaga pendidikan madrasah ini telah tumbuh dan berkembang sehingga merupakan bagian dari budaya Indonesia, karena ia tumbuh dan berproses bersama dengan seluruh proses perubahan dan perkembangan yang terjadi di dalam masyarakat. Dalam kurun waktu yang cukup panjang, yakni kurang lebih satu abad, lembaga pendidikan madrasah telah mampu bertahan dengan karakternya sendiri, yakni sebagai lembaga pendidikan untuk membina jiwa agama dan akhlak anak didik.

Jenjang-jenjang madrasah yang dikelola oleh Departemen Agama (Depag) sangat mirip dengan sekolah-sekolah yang dikelola oleh Depdiknas. Walaupun madrasah memiliki karakteristik dan struktur seperti karakteristik sekolah pada umumnya, madrasah tidak disupervisi oleh Depdiknas tetapi disupervisi oleh Depag sebagaimana ditegaskan oleh Keppres No. 34 (1972). Selanjutnya, Keppres tersebut

${ }^{8}$ Karel A. Steenbrink, Pesantren, Madrasah, sekolab (Jakarta : LP3ES, 1991), hlm. 163

9 Malik Fadjar, Madrasab dan Tantangan Modernitas (Bandung: Mizan, 1998) hlm. 112 bersama dengan Peraturan Pelaksanaannya "Instruksi Presiden" No 15 (1974) memberikan seluruh kewenangan kepada Depdiknas untuk penyelenggaraan pendidikan serta pelatihan di sekolah negeri maupun swasta termasuk pengembangan program-program pendidikannya. ${ }^{10}$ Akan tetapi pada kenyataannya, Depdiknas hanya memiliki kontrol yang terbatas terhadap sekolah dan bahkan sangat sedikit (kalau dikatakan tidak ada) terhadap madrasah.

Seperti halnya pengelolaan sekolah di Depdiknas, pada dasarnya pertanggungjawaban manajemen dan kontrol madrasah juga dapat dikategorikan menjadi dua, yaitu madrasah negeri dan madrasah swasta. Jenis pertama, madrasah negeri, adalah sekolah yang sepenuhnya dikelola dan dikontrol oleh pemerintah (dalam hal ini Departemen Agama); sebaliknya jenis kedua, madrasah swasta adalah madrasah yang hanya dalam hal-hal tertentu saja mendapat bantuan dari pemerintah (misalnya guru yang diperbantukan atau gaji guru, dsb) sehingga madrasah swasta ini tidak sepenuhnya ada dalam pengelolaan serta kontrol pemerintah. Secara kuantitatif, serta berdasarkan jenjang pendidikan, kontribusi madrasah swasta pada pembangunan pendidikan di Indonesia juga cukup bervariasi. Pada jenjang pendidikan prasekolah, kontribusi madrasah swasta sangat besar. ${ }^{11}$

Setelah reformasi ini sangat dituntut perlunya pengelolaan madrasah secara baik, sebab madrasah merupakan salah satu pranata pendidikan yang sangat penting untuk diperhatikan. Pada madrasah banyak putra-putri Indonesia ini terbentuk dan terbina prilakunya dengan baik. Mereka bukan memiliki ilmu kehidupan tetapi juga ada kecenderungan untuk akhirat.

Sejak awal diterapkannya sistem madrasah di Indonesia pada awal abad ke-20, madrasah telah menampilkan identitasnya sebagai lembaga pendidikan Islam. Identitas itu tetap dipertahankan

\footnotetext{
${ }^{10}$ Depag RI, Pendidikan Islam, hlm. 137
}

${ }^{11}$ Ibid. 
kendatipun harus menghadapi berbagai tantangan dan kendala yang tidak kecil, terutama pada masa penjajahan. Sebagaimana diketahui, pada masa itu banyak sekali peraturan-peraturan yang ditarapkan oleh pemerintah Hindia Belanda, yang pada intinya tidak lain adalah untuk mengontrol atau mengawasi madrasah. Karena pemerintah takut dari kebijakan tersebut akan muncul gerakan atau ideologi perlawanan yang akan mengancam kelestarian penjajahan mereka di bumi Indonesia ini. Ekses dari ketakutan yang berlebihan itu mencapai puncaknya ketika banyak madrasah yang ditutup karena dianggap melanggar ketentuan yang digariskan oleh pemerintah Hindia Belanda saat itu. ${ }^{12}$

Ketika Indonesia diproklamasikan sebagai negara merdeka pada 1945, madrasah kembali bermunculan dengan tetap menyandang indentitas sebagai lembaga pendidikan Islam. Dibentuknya Departemen Agama (Depag) pada tahun 1946 telah ikut membuka akses madrasah ke pentas nasional, karena memang salah satu tujuan dari pembentukan Depatemen Agama adalah untuk memperjuangkan politik pendidikan Islam. ${ }^{13}$

Terlepas apakah tujuan itu tercapai atau tidak, yang jelas Departemen Agama telah banyak berbuat untuk memajukan madrasah. Salah satu kebijakan Departemen Agama terhadap madrasah yang cukup mendasar dan dampaknya (baik positif maupun negatif) cukup panjang adalah dibuatnya Surat Kesepakatan Bersama (SKB) 3 Menteri, yaitu Menteri Pendidikan dan Kebudayaan, Menteri Dalam Negeri, dan Menteri Agama Sendiri tentang "Peningkatan Mutu Pendidikan pada Madrasah". ${ }^{4}$ SKB 3 Menteri itu dirasakan

${ }^{12}$ Maksum, Madrasah Sejarah \& Perkembangannya (Jakarta : Logos Wacana Ilmu, 1999) hlm. 76

${ }_{13}$ Ibid.

${ }^{14}$ SKB Tiga Menteri itu dikeluarkan pada tanggal 24 Maret 1975 di Jakarta oleh Menteri Agama Nomor 6 Tahun 1975, Menteri P\&K Nomor 037/u/1975, dan Menteri Dalam Negeri Nomor 36 Tahun 1975, lihat Alamsyah, Pembinaan Pendidikan Agama, (Jakarta: Depag RI, 1982), hlm. 138 cukup mendasar karena melalui SKB ini madrasah telah mulai sejajar kedudukannya dengan sekolah umum. Secara lebih rinci uraian ini bisa dilihat pada bab berikut.

Perhatian pemerintah yang begitu besar di awal kemerdekaan yang ditandai dengan tugas Departemen agama tampaknya tidak berlanjut. Hal ini tampak ketika Undang-Undang Pendidikan Nasional pertama (UU No.4 Tahun 1950 dan UU No. 12 Tahun1954) diundangkan, masalah madrasah tidak dimasukkan sama sekali, yang ada hanya masalah pendidikan agama di sekolah (umum). Dampaknya, madrasah dianggap berada diluar sistem. Oleh karena itu mulai muncul sikap diskriminatif pemerintah terhadap madrasah. Pada tahap ini madrasah belum dipandang sebagai bagian dari sistem pendidikan nasional, tetapi merupakan lembaga pendidikan dibawah Mentri Agama. ${ }^{15}$

Reaksi terhadap sikap pemerintah yang diskriminatif ini menjadi lebih keras dengan keluarnya Keputusan Presiden No. 34 tahun 1972, yang kemudian diperkuat dengan intruksi Presiden No. 15 tahun 1974. Kepres dan Inpres ini isinya dianggap melemahkan dan mengasingkan madrasah dari pendidikan nasional. Bahkan sebagian umat Islam memandang Kepres dan Inpres itu sebagai manuver untuk mengabaikan peran dan manfaat madrasah yang sejak zaman penjajahan telah diselenggarakan umat Islam. ${ }^{16}$

Munculnya reaksi keras umat Islam ini disadari oleh pemerintah yang kemudian mengambil kebijakan untuk melakukan pembinaan mutu pendidikan madrasah. Dan untuk mengatasi kekhawatiran dan kecemasan umat Islam akan dihapuskannya sistem pendidikan madrasah sebagai kongkurensi Kepres dan Inpres di atas, maka pada tanggal 24 Maret 1975 dikeluarkan Surat Keputusan Bersama (SKB) tiga menteri (Mentri Agama, Mentri Pendidikan, dan Kebudayaan, dan

\footnotetext{
15 Maksum, Madrasah Sejarah, hlm. 78
}

${ }^{16}$ Ibid. 
Mentri Dalam Negeri). ${ }^{17}$

SKB Tiga Menteri merupakan model solusi yang di satu sisi memberikan pengakuan eksistensi madrasah, dan di sisi lain memberikan kepastian akan berlanjutnya usaha yang mengarah pada penbentukan sistem pendidikan nasional yang integratif. Dalam SKB tersebut diakui ada tiga tingkatan madrasah, yakni Ibtidaiyah, Tsanawiyah dan Aliyah, yang ijazahnya diakui sama dan setingkat dengan SD, SMP dan SMA. Kemudian lulusannya dapat melanjutkan ke sekolah umum yang setingkat lebih tinngi, serta siswanya dapat berpindah ke sekolah umum yang setingkat. Makna SKB Tiga Menteri ini bagi umat Islam adalah pertama, terjadinya mobilitas sosial dan vertikal siswa-siswa madrasah yang selama ini terbatas di lembagalembaga pendidikan tradisional (madrasah dan pesantren), dan kedua, membuka peluang kemungkinam anak anak santri memasuki wilayah pekerjaan pada sektor modern. ${ }^{18}$

Efek penyamaan kurikulum ini adalah bertambahnya beban yang harus dipikul oleh madrasah. Di situ pihak ia harus memperbaiki mutu pendidikan umumnya setaraf dengan standar yang berlaku di sekolah. Di lain pihak, bagaimanapun juga madrasah sebagai lembaga pendidikan Islam hurus menjaga agar mutu pendidikan agamanya tetap baik. Namun, dengan penguasaan ilmu ilmu agama hanya 30\% termasuk Bahasa Arab, tidak cukup memadai bagi alumni MA untuk memasuki IAIN, apalagi untuk melanjutkan studi di Timur Tengah dan juga menjadi calon-calon ulama.

Demikian juga masih sering lulusan madrasah mendapat perlakuan diskriminatif karena dianggap kemampuan umumnya belum setara dengan sekolah umum. Perlakuan diskriminatif sangat dirasakan ketika mareka akan masuk ke perguruan tinggi ataupun kedunia kerja.

Perjuangan agar mandapat perlakuan yang sama (integrasi

${ }_{17}$ Depag, Desain Pengembangan, hlm. 44

${ }^{18}$ Depag, Pendidikan Islam., hlm. 66 madrasah dalam sisdiknas secara penuh), baru dicapai dalam UUSPN No. 2 Tahun 1989., dimana madrasah dianggap sebagai sekolah umum yang berciri khas Islam dan kurikulum madrasah sama persis dengan sekolah, plus pelajaran agama Islam (7 mata pelajaran). ${ }^{19}$

Kenyataannya beban kurikulum bagi madrasah yang menerapkan kurikulum sekolah 100\% ditambah dengan kurikulum agama sebagai ciri khas telah berakibat beban belajar siswa madrasah menjadi lebih banyak dibanding dengan beban belajar anak sekolah. Padahal kondisi fasilitas dan latar belakang anak cukup berbeda. Oleh karena itu wajar saja bila kwalitas anak madrasah masih kalah dibandingkan dengan anak sekolah. Jadi yang membedakan madrasah dengan sekolah umum sekarang bukan lagi pada bobot pengetahuan umumnya tapi pada kwalitas dan ciri khas madrasah itu sendiri.

Sampai di sini persoalan madrasah sebagai sekolah umum yang berciri khas Islam sudah terselesaikan sebagai bagian dari sistem pendidikan nasional yang diakui sama dengan sekolah. Namun Madrasah sebagai sekolah agama yang memberikan pengetahuan umum sebagai ciri ke Indionesia dan kemodernan belum mendapat tempat dalam sistem pendidikan nasional versi UU No.2 Tahun1989. Hal ini masih mengundang perasaan yang "kurang puas" di kalangan ummat Islam, karena masih ada perasaan pemerintah masih memojokkan madrasah yang porsi pengajaran agama lebih besar di banding pelajaran umum. Juga masih terdengar pendapat yang menyatakan bahwa madrasah sebagai sekolah umum yang berciri khas Islam itu sebagai upaya "mengandalkan agama"20

Tentu prasangka di atas tidak beralasan, karena peminat untuk memasukkan anak ke madrasah sebagai sekolah umum yang berciri khas Islam jauh lebih besar dibanding dengan yang ingin memasukkan anaknya ke sekolah agama yang pengetahuan agamanya lebih besar dari pengetuhuan umum.

\footnotetext{
${ }^{19}$ Ibid., hlm.66
}

${ }^{20} \mathrm{Ibid}$. 


\section{Problematika Madrasah}

Dari semua uraian tentang perkembangan madrasah di atas, dapat dilihat adanya usaha untuk mengelola dan mengembangkan sistem pendidikan di Indonesia dari zaman ke zaman. Semua perubahan itu di sesuaikan dengan tuntutan keadaan yang kian maju: dari sistem pesantren ke madrasah; dari kurikulum tradisional ke kurikulum modern; dari sistem sentralisasi ke desentralisasi.

Akan tetapi perkembangan madrasah di atas belum bisa dianggap sudah cukup, sebab ditengah harapan masyarakat yang belum sepenuhnya terpenuhi tentang peran madrasah sebagai model pendidikan integralistik yang akan mendidik siswa seimbang sisi ukhrawi dan duniawinya, fenomena madrasah nampaknya masih diganggu oleh kesan ganjl yang tersebar di sebagian masyarakat. Masih terdengar kritikan-kritikan yang dilontarkan bahwa madrasah belum siap menghadapi perkembangan dan perubahan zaman. Para lulusan madrasah dianggap belum siap untuk bersaing dengan lulusan sekolah umum dalam mengisi peran-peran yang ada di tengah masyarakat. ${ }^{21}$

Persoalan persoalan tersebut membuat kita bertanya, ada apa sebenarnya dengan pendidikan di madrasah bukankah telah banyak kebijakan untuk pengelolaan yang lebih inten telah di buat, peraturan demi peratuan telah di tetapkan, dan kurikulum pun telah disesuaikan pada setiap perubahan kurikulum yang terjadi; bahkan dalam mata pelajaran umum madrasah sepenuhnya mengadopsi kurikulum nasional yang diterapkan Departeman Pendidikan Nasional terhadap sekolah.

Masalahnya menurut penulis adalah, di tengah gemuruh gelombang semangat otonomi pendidikan, sepertinya ada sesuatu yang tercecer (something left behind), yaitu berkenaan dengan pengelolaan madrasah (MI/MTs/MA). Sebagaimana diketahui, berbeda dengan

21 Ary. H. Gunawan, Kebijakan-kebijakan Pendidikan di Indonesia (Jakarta, Bina Aksara, 1986) hlm 73

28 sekolah umum yang dikelola penuh oleh Departemen Pendidikan Nasional, selama ini madrasah berada di bawah naungan Departemen Agama. Ketika arus otonomi pendidikan mengalir deras, opsi yang dipilih Depag kemudian adalah memepertahankan madrasah tetap di bawah pembinaan Departemen Agama. Konsekwensinya, pengelolaan madrasah masih tetap sentralistis, tidak include dalam semangat otonomi pendidikan yang sudah berkecambah di setiap daerah. Sebenarnya, jauh-jauh hari banyak pihak telah mengingatkan Departemen Agama tentang beberapa akibat negatif yang bakal dihadapi dunia madrasah apabilah tidak include dalam semangat otonomi pendidikan di daerah. Seperti halnya Fuad Fachruddin, menyatakan dengan sangat cerdas dan objektif kemungkinankemungkinan yang akan terjadi apabila pengelolaan madrasah masih sentralistis.

Di antaranya beliau menyebut bahwa kalau pengelolaan madrasah masih sentralistis, maka besar kemungkinan sumber dana yang diterima untuk upaya peningkatan mutu sangat tidak memadai dibandingkan dengan jumlah madrasah dan wilayah yang harus dijangkau. Dengan demikian, masalah kesenjangan politik anggaran yang terjadi sebelum reformasi tidak menemukan jalan keluarnya. Madrasah tetap menjadi sekolah yang serba berkekurangan dan memprihatinkan, baik dari segi fisik, berupa bangunan gedung, buku, pustaka, dan lain-lain, maupun non fisik, berupa kesejahteraan karyawan dan guru. Lebih jauh, beliau mengingatkan apabila pengelolaan madrasah masih sentralistis, maka madrasah bisa tidak diangap sebagai bagian dari sistem pendidikan nasional, ${ }^{22}$ karena berdasarkan UU No.22 tahun 1999, pendidikan diserahkan ke Pemerintah Daerah Tk.II. ${ }^{23}$

${ }^{22}$ Fuad Fakhruddin, dalam tulisannya pada Jurnal Madrasah Vol.3 No.1 tahun 1999 yang berjudul Madrasah dan Otonomi Daerab; Sebuab Telaah Awal dimuat dalam: http//www.Fuadfakhruddin.tripod.com/urintia-indonesia/htm

${ }^{23}$ Undang-Undang No. 22 Tahun 1999 Tentang Pemerintah Daerah, Jakarta: CV. Novindo Pustaka Mandiri, hlm. 6 
Di bawah ini penulis akan melihat beberapa fakta permasalahan yang masih dihadapkan pada pendidikan madrasah. Permasalahan ini tentu menuntut penyelesaian segera. Diantaranya adalah:

1. Kurang Mendapatkan Perhatian dari merintah Daerah

2. Birokrasi yang Berbelit-belit

3. Anggaran Minim

4. Kesejahteraan Guru dan Karyawan Kurang Diperhatikan

5. Guru Agama Masih Diperlakukan Diskriminatif

6. Sarana dan Prasarana yang terbatas

7. Madrasah Negeri Minim

8. Kekurangan Guru

9. Kualitas Guru Masih Rendah

10. Kualitas Kepala Madrasah dan Pengawas Masih Rendah

\section{Pembinaan Madrasah}

1. Pengembangan Pembinaan Madrasah

Tatanan masyarakat baru menuntut adanya keterbukaan dalam politik, pembagian kekuasaan serta sumber daya alam, menghargai hukum dan hak asasi manusia serta transparansi dalam kebijakan pemerintah. Atas dasar inilah, maka memasuki era baru masyarakat menghendaki adanya desentralisasi serta otonomi dalam mengambil kebijakan pembangunan. Keinginan ini telah dituangkan melalui Undang-Undang No. 22 Tahun 1999 tentang Pemerintah dan Daerah $^{24}$ serta Peraturan Pemerintah No. 25 Tahun 2000 tentang Kewenangan Pemerintah dan Kewenangan Provinsi sebagai Daerah Otonomi.

Perubahan yang terjadi pada gilirannya akan memengaruhi tata nilai kehidupan masyarakat yang mungkin sama sekali baru dan berbeda dengan gaya nilai yang sekarang dianut masyarakat. Para proses perubahan ini, kesiapan lembaga pendidikan dan institusi sosial

24 Undang-Undang No. 22 Tahun 1999 Tentang Pemerintah Daerah, (Jakarta: CV. Novindo Pustaka Mandiri, 2001), hlm. 10

30 lainnya menjadi sangat penting. Sebab masyarakat yang berbeda pada proses transisi kultural sangat labil pada berbagai benturan nilai.

Salah satu insititusi sosial dan kultural yang sentral dapat berperan besar dalam mengatur irama perubahan tersebut adalah lembaga pendidikan. ${ }^{25}$ Kedudukannya yang sentral dan direncanakan secara sistematik. Kedudukannya yang sentral diharapkan dapat menjadi perisai bagi perkembangan budaya serta menjadi motor untuk mempercepat perubahan masyarakat. Peran ini akan berjalan positif bila institusi pendidikan ditempatkan pada posisi searah pada cita-cita sosial yang diinginkan masyarakat. Bila tidak demikian, maka institusi pendidikan akan hidup terasing dari masyarakat yang mendukungnya. ${ }^{26}$

Dalam konteks di atas, maka institusi pendidikan Islam diharapkan dapat menjadi salah satu kekuatan yang dapat memberikan kontribusinya untuk pembentukan kultural Indonesia Baru yang berdasarkan pada nilai-nilai transendental. Tanpa ada rujukan nilai yang bersifat membimbing masyarakat baru pada era mendatang akan mengalami distori nilai dan rusaknya fondasi sosio-kultural masyarakat yang menjadi ciri dari bangsa Indonesia. ${ }^{27}$

Pembinaan pendidikan yang dilakukan oleh Departemen Agama selama ini masih perlu langkah-langkah penyesuaian yang strategis, utamanya dalam rangka mencari bentuk dan pemecahan masalah sehubungan dengan kemungkinan diberlakukannya Desentralisasi di bidang pendidikan secara keseluruhan. Sementera itu madrasah telah tumbuh dan berkembang menjadi bagian dari kebudayaan Bangsa Indonesia. Oleh karena itu, madrasah merupakan milik Bangsa Indonesia. Oleh karena itu, madrasah merupakan milik Bangsa Indonesia dan telah ikut serta mencerdaskan kehidupan bangsa.

25 Marwan Saridjo, Bunga Rampai Pendidikan Agama Islam, Jakarta: CV. Amisco, 1996), hlm. 32

${ }^{26}$ Nizar, Sejarah Pendidikan Islam, hlm. 360

${ }^{27}$ Ibid. 
Dengan demikian madrasah yang telah menyatu dalam tata nilai budaya merupaka bangsa merupakan modal dasar bagi pembangunan agama yang pengembangannya menuntut pola pembinaan yang berorientasi ke masa depan yang lebih baik. ${ }^{28}$ Usaha ke arah pengembangan pembinaan madrasah adalah sebagai kerangka dasar strategis pengembangan madrasah pada umumnya secara bertahap perlu dikembangkan sejalan dengan tuntutan dan perkembangan masyarakat yang penjabarannya lebih lanjut dituangkan dalam berbagai peraturan dan pedoman pelaksanaannya yang operasional. ${ }^{29}$ Pengembangan pembinaan madrasah dimaksudkan di dalamnya mencakup satu pilihan sistem, pendekatan, sumber dana dan sarana yang betul-betul diperlukan untuk mencapai sasaran dan tujuan pembangunan.

Dalam perkembangan sistem pendidikan pada madrasah telah terjadi penyesuain-penyesuaian melalui pembaharuan dan inovasi pada fase awalnya dengan pola pondok pesanten kemudian menjadi madrasah seperti yang kita kenal saat ini. Posisi stretagis usaha pengembangan di bidang pendidikan pada madrasah sedikitnya dapat dilihat dari dua segi, yang pertama, dari segi kedudukannya sebagai bagian integral dari kesatuan Pendidikan Nasional. Dalam hal ini madrasah dituntut untuk mampu memenuhi tuntutan dan kebutuhan masyarakat, di samping harus memilki hubungan yang akrab dengan sistem Pendidikan Nasional itu sendiri. Kedua, dari segi kedudukannya sebagai bagian tepenting dari pembangunan sektor agama yang merupakan bagian integral dari pembangunan nasional. Dalam hal ini, setiap upaya pengembagan madrasah harus mengacu agar madrasah dapat menunjang pembangunan sektor agama secara keseluruhan dengan tetap memelihara identitas dan kerakteristiknya sendiri sebagai

${ }^{28}$ Depag, RI. Sejarah Madrasah : Pertumbuhan, Dinamika, dan Perkembangannya di Indonesia, (Jakarta, Dirjen Agama Islam, 2004), hlm.127

29 Abdul Rachman Shaleh, Madrasah dan Pendidikan Anak. Bangsa Visi, Misi dan Aksi , (Jakarta: RajaGrafindo, 2005), hlm. 78 sektor agama dan lembaga keagamaan. ${ }^{30}$

Dengan demikian pengembangan pembinaan madrasah pada masa mendatang diorientasikan untuk menciptakan situasi yang kondusif agar dapat melakukan adaptasi dan akomodasi terhadap tuntutan program pendidikan dan tetap memelihara bobot dan identitas ciri khususnya sebagai lembaga pendidikan keagamaan.

Selain posisi madrasah yang berada antara dua kutub tersebut, juga posisi eksternal masih banyak yang belum menunjang pembinaan madrasah secara optimal. Kondisi tersebut antara lain tidak memadainya dana yang diperlukan, kurangnya tenaga guru dan tenaga kependidikan lainnya yang memenuhi persyaratan, kurangnya tenaga administratif dan perencana pendidikan yang memiliki kemampuan serta kendala-kendala lain yang kurang menunjang. Dalam posisi yang demikian para pemegang kebijakansanaan, perencana dan pengelola madrasah dituntut untuk mampu memiliki strategi pembinaan madrasah yang tepat dan operasional berdasarkan peraturan perundang-undangan yang berlaku khususnya pada era desentralisasi yang secara formal telah diberlakukan tanggal 1 Januari 2001.31

\section{Desentralisasi Dan Otonomi Daerah}

Dalam pengembangan demokrasi dan menegakkan hak asasai serta membina bangsa Indonesia pada kehidupan yang lebih maju dan bermartabat, salah satu keputusan dan kemauan politik adalah ditetapkannya Desentralisasi dan Otonomi Daerah. Pemikiran dan kemauan ini telah dituangkan dalam Undang-undang No. 22 dan 25 Tahun 1999, tentang Pemerintahan Daerah dan tentang Perimbangan Keuangan antara Pusat dan Daerah. ${ }^{32}$ Apabila dianalisa tersebut, maka dapat diungkap dua hal pokok, yaitu perubahan : Pertama, adanya piramida kewenangan pemerintahan, Pasal 10, meletakkan otonomi

${ }^{30}$ Depag, Pendidikan Islam, hlm. 128

31 Shaleh, Madrasab dan Pendidikan, hlm. 79

32 Undang-Undang No. 25 Tahun 1999 Tentang Pemerintah Daerah, (Jakarta: Biro Humas Departemen Dalam Negeri 2000), hlm. 7 
luas dan utuh pada daerah Kabupaten/Kota (semua kewenangan dan aktualitasnya, kecuali pasal 27). Pasal 9 merupakan otonomi provinsi adalah otonomi terbatas dan Pasal 112 provinsi diamanatkan sebagai fasilitator dan perakat. Kedua, Pembangunan Paradigma di antaranya: demokrasasi penyelenggarakan program, pemberdayaan aparat dan masyarakat (peningkatan partisipasi dan tanggung jawab), dan Peningkatkan pelayanan umum kepada masyarakat (pengembangan kewajiban dan hak sipil).

Undang-undang No. 25 Tahun 1999 sebagai perimbangan pendapatan antara Pemerintah Pusat dan Pemerintah Daerah sebagai dasar akselerasi terhadap penataan organisasi yang adaptif dan fleksibel serta proaktif dan operasional kreatif dan kolaboratif. Keuangan merupakan motor penggerak terlaksananya Undangundang No. 22 secara dinamis dan bermanfaat.

Secara populer desentralisasi diartikan sebagai pemberian/pendelegasian kewenangan, umumnya dari pemilik wewenang (atasan) pada pelaksana (penguasa di bawahnya). Jadi desentralisasi berarti give greater power (for self-government etc) to places, branches etc. away from center. dalam pengertian ini desentralisasi berhubungan dengan pendelegasian/delegasi. ${ }^{33}$

Rabbin, berpendapat bahwa : The extent to wich authority is delegeted with organization is a measure of the degree of cenrralization and decentralization with ini that organization ${ }^{34}$. Pendapat Robbin ini menggambarkan hubungan antara sentralisasi dengan wewenang yang ada penguasa yang lebih tinggi dengan penguasa di bawahnya (pemerintahan pusat ke Provinsi dan provinsi ke Kabupaten/Kota). Selanjutnya Edward berpendapat bahwa : The concept of centralization and decentralization is

33 Mattulada, Desentralisasi Pendidikan dalam Pelaksanaan Manajemen Pembangunan, (Jakarta: Pustaka Sinar Harapan, 1990), hlm. 99

34 Robin, dalam: Husni Rahim, Arah Baru Pendidikan Islam Indonesia, (Jakarta: Logos, 2001), hlm. 104

34 relating to the hearchical leverl at which decision-making authority is concetrated. ${ }^{35}$ Konsep sentralisasi berkaitan dengan konsisten dalam pemusatan pengambilan keputusan dalam arti bahwa dalam pengambilan keputusan yang berhubungan dengan kepentingan organisasi/lembaga. Faktor inilah yang menjadi karakteristik dan ciri terjadi desentralisasi.

Desentralisasi pendidikan mengandung arti sebagai pelimpahan kekuasaan oleh pusat kepada aparat pengelola pendidikan yang ada di daerah baik pada tingkat provinsi maupun lokal, sebagai perpanjangan aparat pusat untuk meningkatkan efesiensi kerja dalam pengelolaan pendidikan. Pelaksanaan desentralisasi pendidikan, mencakup aspek substantif yang meliputi teknis edukatif, personel, finansial, sarana dan prasarana, administratif, dan aspek fungsi manajemen. ${ }^{36}$

Dengan demikian desentralisasi merupakan pemberian kewenangan dalam pengambilan keputusan para manajer (penguasa) di bawahnya, pengambilan keputusan dimaksudkan mempunyai arti : Pertama, menetapkan peraturan (pelaksanaan) berkaitan/sesuai/adaptif pada wilayahnya. Kedua, melaksanakan peraturan tersebut demi kemajuan daerah (termasuk rakyat) yang berada dalam kewenangan dan tanggung jawabnya.

Adapun pengertian otonomi secara umum mengandung pengertian sendirinya, ada juga memberi arti kemandirian. Kemandirian ini dalam konteks bebas dalam wujud memilih yang disertai adanya kemampuan. Kemampuan memilih secara esensial mencakup:

1. Kemampuan memilih membuat keputusan yang terbaik (tepat dan berguna) untuk diri, kelompok (daerah)

2. Kemampuan memilih mengakui/menghargai pendapat yang

35 Edward B. Fiske, Desentralisasi of Education: Politics and Consensus (New Jersey: Engliwood Cliffs, 1979), hlm.. 33

36 Darmuin, Prospek Pendidikan Islam di Indonesia: Suatu Telaah terhadap Pesantren dan Madrasah, (Jakarta: Novindo Pustaka Mandiri, 2004), hlm. 56 
lain (untuk diri, kelompoknya (daerah)

3. Kemampuan memilih pelaksanaan yang tepat (pertama dan prioritas) bagi daerahnya)

4. Kemampuan memilih pelaksanaan yang tepat (pertama dan prioritas) bagi daerahnya

5. Kemampuan memilih sesuatu untuk melengkapi (memenuhi) kebutuhan daerahnya

6. Kemampuan memilih mengatasi (solving) dan untuk menyesuaikan diri

Dengan demikian pelaksanaan desentralisasi dan otonomi daerah menggambarkan hal-hal sebagai berikut:

1. Keputusan politik ditentukan oleh rakyat melalui DPRD

2. Kekuasaan di tengah Kepala Daerah Tingkat II

3. Daerah Tingkat II diberi wewenang untuk mengurus kepentingan masyarakat

4. Mengatur kebijaksanaan wilayah bersama DPRD Tingkat II

5. Meliputi aspek, ekonomi, politik dan sosial budaya serta semua sektor pembangunan

6. Kewenangan bidang agama dapat ditugaskan ke daerah

7. Penggunaan sumber daya ditentukan oleh daerah berimbang

8. Otonomi daerah dalam rangka Ikatan Negara Kesatuan Republik Indonesia

9. Ketergantungan Pusat dan Daerah secara politis semakin kecil

10. SD/MI-SLTP/MTs-SMU/MA pengelolaannya dilakukan dalam satu atap, mengingat madrasah adalah jenis pendidikan umum. ${ }^{37}$

Implikasi desentralisasi pendidikan adalah adanya kewenangan yang lebih besar yang diberikan kepada kabupaten/kota untuk mengelola pendidikan sesuai dengan potensi dan kebutuhan daerahnya; adanya perubahan kelembagaan untuk memebuhi kebutuhan dan meningkatkan efesiensi serta efektivitas dalam

\footnotetext{
37 Shaleh, Madrasah dan Pendidikan, hlm. 128
}

perencanaan dan pelaksanaan pada unit-unit kerja di daerah; kepegawaian yang menyangkut perubahan dan pemberdayaan sumber daya manusia yang menekankan pada profesionalisme; serta perubahan-perubahan anggaran pembangunan pendidikan (DIP) yang dikelola langsung dari BKPN (Bappenas) ke kabupaten dalam bentuk block grand. Sehingga menghilangkan ketakukan dan pengkotakan dalam anggaran. ${ }^{38}$

3. Desentralisasi Bidang Pendidikan

Kebijakan yang berkaitan dengan desentraliasi berlaku juga dalam pendidikan disertai dengan karakteristik khusus. Pertama, Manajemen, karena dalam manajemen pendidikan bertujuan untuk mewujudkan manusia seutuhnya (lihat GBHN) dan tumbuh kembang di atas budayanya sendiri secara normaif. Kedua, Perencanaan, tercapainya tujuan wujud manusia-manusia yang utuh (cerdas, terampil, religius, berbudi perkerti luhur dan warga negara yang bertanggung jawab). ${ }^{39}$

Menurut Mattulada perencanaan pendidikan dalam desentraliasi memiliki karakteristik sebagai berikut:

a. Untuk perencana yang lebih rendah mempunyai wewenang untuk memformulasikan targetnya sendiri

b. Unit perencanaan lebih rendah diberi kewenangan dan kekuasaan untuk memobilisasi sumber-sumber yang ada, dan kekuasaan untuk melakukan realokasi sumber-sumber yang telah diberikannya sesuai dengan kebutuhan prioritasnya

c. Unit perencana yang lebih rendah turut berpartispasi dalam proses perencanaan dengan untuk yang lebih tinggi (provinsi dan atau pusat di mana posisi unit yang lebih rendah bukan sebagai "bawahan" melainkan sebagai "parter" dari unit

38 Kompas. Kamis, 05 Desember 2002, "Mulai Dihapus, Dikotomi Sekolah Umum-Madrasab"

${ }^{39}$ Ibid., hlm.129 
provinsi dan/atau pusat) ${ }^{40}$

Pada era desentralisasi perlu didorong tumbuhnya prakarsa dan kreaktivitas serta meningkatnya peran serta masyarakat. Di samping itu diharapkan meningkat pula fungsi peran aparat kabupaten/kota, karena daerah lebih membutuhkannya, sehingga keputusan, memutuskan kebijaksanaan, menyusun rencana serta menentukan langkah-langkah pelaksanaannya. ${ }^{41}$

Desentralisasi tidak berarti meninggalkan kepentingan pendidikan nasional menuju pada pendidikan sempit/lokal (subsitusinya), serta berorientasi yang bersifat primordial yang hanya dapat membutuhkakn sentimen kedaerah yang stereotip. Namun, pemberian kewenangan dan kemudian memilij kemandirian yang benar dan baik dan kemandirian memilih kemandirian yang benar dan baik dan memberi manfaat di atas kebhinekaan (karena kesejahterannya) dan lingkup Tunggal Ika yang mandiri. Dengan mekanisme pelaksanaan demikian, pendidikan akan lebih proporsional, bermanfaat serta efisien dan efektif. ${ }^{42}$

Kebijaksanaan dalam konteks Undang-Undang No 22 dan 25 Tahun 1999 lebih menampilkan pengembangan potensi kabupaten/kota berkaitan dengan SDA dan SDE (Sumber Daya Alam-Sumber Daya Energi) dan melanjutkan peningkatan mutu. Ungkapan itu pada dasarnya mengatur pemberian kewenangan kepada daerah otonom untuk mengatur dan mengurus kepentingan masyarakat setempat atau dan mengurus kepentingan masyarakat setempat menurut prakarsa sendiri berdasarkan asprasi masyarakat sesuai dengan peraturan perundang-undangan. Kewenangan yang diberikan itu bersifat untuh mulai dari perencanaan, pelaksanaan, pengawasan, pengendelian dan evaluasi. Tujuannya adalah untuk mendorong, memberdayakan masyarakat, mengembankan peran dan

${ }^{40}$ Mattulada, Desentralisasi Pendidikan, hlm. 101

${ }^{41} \mathrm{Ibid}$.

${ }^{42}$ Fachruddin, Madrasah dan Otonomi, hlm.7 fungsi Dewan Perwakilan Rakyat. Dengan demikian, dasar pemikiran yang mendasari Undang-Undang No. 22 Tahun 1999. Pertama, dalam rangka memberikan keleluasaan kepada daerah untuk menyelenggarakan otonomi daerah. Kedua, penyelenggaraan otonomi daerah itu diharapkan dilakukan dengan prinsip demokrasi, peran serta masyarakat, pemerataan dan keadilan, kemandirian dengan memperhatikan potensi dan keanekaragaman, menjaga keserasian hubungan pusat dan daerah serta meningkatkan peran dan fungsi legislatif, asas desentralisasi disertai dengan dukungan pembiayaan. Ketiga, itu semua dimaksudkan guna menghadapi tantangan persaiangan global dengan memberikan kewenangan luas, nyata dan bertanggung jawab secara professional. ${ }^{43}$

Undang-undang No. 25 Tahun 1999 mengatur kewenangan antara pusat dengan daerah bertujuan : Pertama, menciptakan sistem pembiayaan yang adil, profesional partisipasi atau transparan. Kedua, memberdayakan dan meningkatkan kemampuan dan dinamika ekonomi daerah. Ketiga, mengakselerasi potensi daerah dalam bidang Sumber Daya Alam (SDA) dan Sumber Daya Energi (SDE). Keempat, membangun sistem dan keuangan antara pusat dan daerah yang pasti dan jelas. Kelima, menambah volume pendapatan daerah tidak hanya dari pendapatan daerah asli, tetapi juga dari APBN. ${ }^{44}$

Berkaitan dengan keuangan tersebut di atas perlu mendapat perhatian dengan ada kelebihan keterbatasan keuangan dengan dilimpahkannya ke daerah, diperlukan "pengelolaan dan perencanaan" akurat (keadaan ini akan berpengaruh pada penyelenggaraan pendidikan dengan berpengharapan pendidikan akan maju dan baik).

Sekarang sudah ada dasar hukum pengaturan pendidikan yang menunjukkan tidak ada jarak pemisah antara pendidikan sekolah dengan pendidikan madrasah. Ini berarti pendidikan sekolah didesentralisasi tentu pendidikan madrasah juga harus

${ }^{43}$ Shaleh, Madrasab dan Pendidikan, hlm. 129

44. Ibid., hlm. 130 
didesentralisasikan. Ini tertuang secara jelas dalam UU No. 20 Tahun 2003 Sisdiknas.

\section{Semangat Desentralisasi Madrasah dalam Undang-undang Sisdiknas No. 20/2003.}

Upaya peningkatan kualitas pendidikan madrasah mulai menemukan momentumnya ketika Undang-undang No. 2 tahun 1989 tentang Sistem Pendidikan Nasional ditetapkan. Produk hukum pertama inilah yang menyatakan kesederajatan antara madrasah dengan sekolah. Dengan ditetapkannya undang-undang ini, maka pendidikan madrasah telah diakui sebagai sub-sistem pendidikan nasional. Madrasah diredefisikan sebagai sekolah umum berciri khas Islam. Sejak itu dualisme sistem pendidikan di tanah air selama ini praktis runtuh dengan adanya undang-undang ini.

Secara legal, madrasah sudah terintegrasi dalam sistem pendidikan nasional sejak di-berlakukannya Undang-Undang (UU) Nomor 2 Tahun 1989 tentang Sistem Pendidikan Nasional. Perkembangan madrasah kemudian berlangsung cepat. Di tingkat MI, siswanya mencapai 11 persen dari total siswa tingkat dasar. Di tahun 1999, terdapat 21.454 MI dan sekitar 93,2 persennya diselenggarakan oleh pihak swasta. Di MTs pendaftarnya mencapai 18,35 persen dari total siswa tingkat lanjutan pertama. Tahun 1999 terdapat 9.860 madrasah dan sekitar 88,1 persennya merupakan madrasah milik swasta. ${ }^{45}$

Dengan demikian penerapan undang-undang No. 2 tahun 1989 dan dikuatkan lagi dengan undang-undang No. 20 tahun 2003 tentang Sisdiknas merupakan implementasi dari kometmen pemerintah bersama DPR untuk memberdayakan dan meningkatkan mutu pendidikan madrasah. Penerapan kedua undang-undang ini harus pula dilihat sebagai upaya menjadikan madrasah sebagai "Center of excellence" pusat keunggulan; karena madrasah memiliki keunggulan komperatif, yaitu penekanan yang signifikan pada pendidikan agama dan akhlak (maralitas), disamping penekanan pada pendidikan umum berupa pemberian pelajaran umum. ${ }^{46}$

Secara sosiologis meningkatnya kepedulian kepada Islam ini membuat banyak kalangan orang tua, khususnya "kalangan kelas menengah" muslim yang tumbuh (muslim rising middle class), semakin berusaha mendapatkan pendidikan Islam yang berkualitas bagi anakanak mereka. Keinginan mereka pada dasarnya adalah mendapatkan pendidikan plus Islam, di mana peserta didik tidak hanya bergumul dengan ilmu-ilmu yang penting untuk kehidupan masa kini di dunia ini, tetapi juga ilmu-ilmu dan amal Islam. ${ }^{47}$ Keunggulan madrasah nantinya terletak pada inovasi yang bisa ditumbuhkan untuk memamfaatkan lowongan yang tersedia dari aturan penyelenggaraan pendidikan yang ada. Karena UU No. 20 tahun 2003 Sisdiknas in memberikan kesempatan besar untuk berinovasi bagi pendidikan madrasah. ${ }^{48}$

Semangat reformasi pendidikan yang ada dalam UU No. 20 tahun 2003 Sisdiknas ini sebenarnya memang sudah mengarah pada kecenderungan memberikan ruang keluasan bagi kreaktifitas melalui sistem desentralisasi yang diusung oleh UU Sisdiknas ini sejak awal. ${ }^{49}$ Lahirnya Undang-Undang No. 20 Tahun 2003 tentang Sisdiknas, disamping bertujuan untuk merevisi terhadap Undang-Undang Sistem Pendidikan nasional no. 2 tahun 1989 agar selaras dengan kebijakan pendidikan pemerintah, khususnya kebijakan desentralisasi dan otonomi daerah, pada sisi lain merupakan pengukuhan kembali stasus madrasah sebagai bagian yang tak terpisahkan dari sistem pendidikan nasional. Bahkan dalam undang-ungang ini, eksistensi kesederajatan medrasah dengan sekolah semakin kuat dan pengakuan terhadap bentuk-bentuk pendidikan Islam lainnya, seperti Pondok Pesantren

${ }^{46}$ Depag Pendidikan Islam hlm. 138

${ }^{47}$ Muchtar Buchori, Agama dan Iptek (IKIP Muhamadiah, 1987), hlm. 76 48 Ibid.

${ }^{49}$ Depag, Pendidikan Islam., hlm. 140 
dan Pendidikan Keagamaan semakin ekplisit. ${ }^{50}$

Bahkan dalam undang-undang ini Departemen Agama diberi peluang baru untuk mendirikan Madrasah Aliyah Ketrampilan sebagai padanan paralel dengan Sekolah Menengah Kejuruan yang ada pada Departemen Pendidikan. Seluruh ketetapan ini merupakan sebuah peluang sekaligus tantangan yang berat bagi pendidikan madrasah ke depan. ${ }^{51}$ Kehadiran Undang-Undang No. 20 Tahun 2003 telah membuka peluang yang besar bagi upaya pengelolaan dan pengembangan institusi pendidikan yang bernama madrasah ini kea rah yang lebih baik bahkan berpeluang menjadi bentuk "pendidikan alternatife" bagi masyarakat Indonesia di masa depan. ${ }^{52}$

Dengan keunggulan komperatif yang dimiliki madrasah, yaitu pendidikan moral yang ditawarkannya menjadi daya tarik yang kuat bagi orang tua untuk memasukkan anaknya ke madrasah. Tetapi masalahnya adalah bagaimana pendidikan madrasah ini mempunyai kesiapan untuk memberi pelayanan pendidikan yang diharapkan para orang tua di atas. Kondisi yang masih nyata sekarang adalah sebagian besar madrasah sangat lemah di hampir semua komponennya. Untuk itu sudah dilakukan pembenahan-pembenahan yang mendasar terhadap sistem pendidikan madrasah; mulai dari mereposisi pendidikan madrasah melalui reformulasi paradigma baru pengelolaan madrasah, perumusan visi, misi dan tujuan utama pendidikan madrasah, pengembangan kurikulum yang berbasis kompetensi yang jelas dan terukur, pengembangan manajemen yang efesien dan efekteif, sampai pada upaya yang serius terhadap pengembangan sistem evaluasinya. ${ }^{53}$

Selain itu perlu diberikan perhatian yang besar terhadap pengembangan program kejuruan yang benar-benar sesuai dengan

\footnotetext{
${ }^{50}$ Ibid.

${ }^{51}$ Ibid.

${ }^{52}$ Ibid, hlm. 141

${ }^{53} \mathrm{Ibid}$.
}

karakter dasar pendidikan madrasah serta mampu menjawab kebutuhan dunia usaha dan industri akan tenaga-tenaga kerja yang terampil disatu dimensi dan bermoral/berakhlak yang terpuji pada dimensi yang lain. Keberhasilan merumuskan disain besar pengembangan madrasah yang realistis dan mampu melihat jauh ke depan merupakan keharusan yang tidak dapat ditunda-tunda lagi.

Lahirnya UU No 20 Tahun 2003 Sisdiknas ini merupakan salah satu reformasi pendidikan yang selama ini dinantikan sebab di dalamnya telah memuat aspirasi yang selama ini diusulkan kepada pemerintah. ${ }^{54}$ Di dalam UU ini terlihat dasar hukum mengenai Pendidikan Nonformal yang selama ini belum jelas nasibnya sekarang sudah terjawab. Juga mengenai wajib belajar dan standar pendidikan Nasional yang digunakan sebagai acuan kurikulmun. Termasuk juga aturan kesejatraan tenaga pendidikan dan kewajiban yang mereka jalankan. Juga manajemen berbasis sekolah (MBS), serta peran serta masyarakat (PSM), dan sebagainya yang menyakut pengelolaan pendidikan madrasah. Untuk lebih jelasnya di bawah ini bisa diikuti uraian pasal dan ayatnya:

1. Pendidikan Nonformal

2. Wajib Belajar

3. Standar Nasional Pendidikan (SNP)

4. Kurikulum

5. Pendidik dan Tenaga Kependidikan

6. Sarana dan Prasarana Pendidikan

7. Pendanaan Pendidikan

8. Pengelolaan Pendidikan

9. Peran Serta Masyarakat

10. Evaluasi, Akreditasi dan Sertifikasi

Bila mengkaitkan muatan UU No. 20 Tahun 2003 dengan SKB Tiga Menteri 1975 yang mengacu pada asas Pancasila, GBHN (TAP MPR Nomor II/MPR/1990); Menag Nomor 6 tahun 1975;

${ }^{54}$ UU No. 20/2003 Sisdiknas, hlm. 13 
Mendiknas Nomor 037/U/1975; Mendagri Nomor 36 tahun 1975; Kepmenag, Kepmentrans, dan Menkop Nomor 46/A/1972, 186/Kpts/Mentranskop/O/1972 tanggal 1 Mei 1972. Subtansi kebijakan tersebut bertujuan: Pertama, meningkatkan mutu pendidikan pada madrasah agar tingkat pelajaran umum dari madrasah $( \pm 70 \%)$ mencapai tingkat yang sama dengan mata pelajaran umum, sehingga ijazah bernilai sama, lulusan sama, dan siswa mempunyai peluang sama. Kedua, peningkatan mutu madrasah di bidang kurikulum, buku pelajaran, sarana prasarana, alat pembelajaran dan pengajar (Guru). Ketiga, tugas pembinaan: a). pengelolaan : Menteri Agama; b). pembinaan pelajaran Agama : Menteri Agama; c) pembinaan dan pengawasan mutu pelajaran umum: Menag, Mendikbud, dan Mendagri. Keempat, bantuan pemerintah pusat ke madrasah: a). mata pelajaran umum; b). sarana fisik melalui upaya : pelatihan dan perbantuan mengajar; c). sarana fisik dan RKB; diatur lebih lanjut oleh 3 Menteri. Kelima, beban anggaran: Pembinaan melalui Depag, sedang bantuan melalui Dikbud dan Depdagri. ${ }^{55}$ Walaupun SKB tersebut sudah dianggap tidak berlaku lagi setelah terbitnya UU Sisdiknas 2003, namun bisa dijadikan sebagai tolak ukur yang melatarbelakangi legalitas madrasah. ${ }^{56}$

\section{Peningkatan Mutu Pendidikan Madrasah}

Sampai 2007, lembaga pendidikan yang berada di lingkungan Depag total 206.425 unit dengan 19.707.484 peserta didik. Dengan rincian, 17.054 Raudlatul Athfal (RA) setingkat TK dengan 714.567 siswa, 40.258 Madrasah baik Ibtidaiyah, Tsanawiyah dan Aliyah (setingkat SD, SMP dan SMA) dengan 6.026.965 siswa, 14.798 pondok pesantren dengan 3.464.334 siswa. Selain itu, Madrasah Diniyah (pendidikan agama informal) dengan 2.927.183 siswa, dan 106.617 Taman Pendidikan al-Quran (TPQ) dengan siswa 6.574.435

${ }^{55}$ Depag, Pendidikan Islam, hlm. 146

56 A. Malik Fadjar, Holistika Pemikiran Pendidikan, (Jakarta, Raja Grafindo, 2005), hlm. 56 siswa $^{57}$

Hingga saat ini madrasah masih bertahan dan setia dalam mengembangkan masyarakat Indonesia, termasuk setia pada keberpihakannya pada masyarakat golongan bawah. Sudah saatnya madrasah mendapat penghargaan lebih. ${ }^{58}$ Menilik daripada perjalanan jatuh bangunnya madrasah dalam pentas pendidikan di Indonesia, sebuah kesimpulan yang perlu di bebaskan adalah kultur madrasah yang soft culture, yaitu adanya sebuah budaya kelemahkarsaan dalam membangun jati dirinya, sehingga madrasah terombang ambing dalam kecepatan perubahan yang terjadi. ${ }^{59}$

Sesungguhnya Departemen Agama yang pada umumnya sebagai pemilik madrasah sudah harus mempunyai ruang wacana yang konstruktif ke arah mana madrasah ini digiring sehingga madrasah mampu tampil dengan jati dirinya yang sesungguhnya, tidak bermain dalam "ikut-ikutan", seperti yang terlihat selama ini. Permasalahan mutu, harus dilihat secara holistik, tidak hanya dilihat dari segi minimnya dana pendidikan yang dikucurkan pemerintah tetapi juga harus dilihat dari peta "dalam" yang berlaku dalam madrasah. Penglihatan peta dalam ini, yang paling urgen tentang bagaimana madrasah berkontestasi selama ini perlu dicerna oleh Depertemen Agama.

Upaya percepatan peningkatan mutu pendidikan madrasah tersebut merupakan prioritas utama yang sedang diupayakan oleh pemerintah melalui Departemen Agama. Departemen Agama sebagai bagian penting dalam dunia pendidikan Indonesia, menterjemahkan peningkatan mutu kepada Peningkatan kualitas tenaga kependidikan dan siswa di setiap tingkatan pendidikan yang meliputi siswa Madrasah Ibtidaiyah (MI), Madrasah Tsanawiyah (MTs) dan Madrasah Aliyah

${ }^{57}$ Nani, Membedah Akar, hlm. 8

${ }^{58}$ Fakhruddin, Madrasah dan Otonomi, hlm. 5

${ }^{59}$ Ibid. 
(MA). ${ }^{60}$

Penulis membaca, memang akhir-akhir ini banyak perlakuan khusus (istimewa) kepada madrasah untuk mengejar ketertinggalannya dibanding sekolah umum yang selama ini madrasah tetap mengalami kemerosotan baik dari segi anggaran maupun yang lainnya. Kendati urusan pengelolaan madrasah belum efektif didesentralisasikan dari pemerintah pusat (Departemen Agama) ke pemerintah kabupaten/kota, Depdiknas dalam beberapa tahun terakhir telah menyertakan madrasah dalam berbagai proyek peningkatan mutu pendidikan. Antara lain, dalam program Jaring Pengaman Sosial (JPS), penyaluran Dana Bantuan Operasional (DBO), beasiswa dan bantuan lainnya.

Selain itu adanya beasiswa untuk lulusan Madrasah Aliyah di pelosok-pelosok untuk masuk ke universitas-universitas unggulan seperti UGM, ITS, IPB dan lainnya. Selain itu program menyekolahkan guru-guru madrasah di 15 universitas unggulan untuk mata pelajaran umum seperti matematika dan lainnya. ${ }^{61}$ Maftuh Basyuni mengatakan Pihak Depag juga mulai melaksanakan program bantuan Rp500 juta untuk sejumlah madrasah yang mengajukan perubahan terukur. Juga sudah menetapkan dari 90 persen anggaran pendidikan di luar gaji guru dialokasikan untuk madrasah swasta di daerah-daerah, baik sekolahnya, gurunya dan siswanya. ${ }^{62}$

Sebagai salah satu perlakuan nyata juga, dalam rangka percepatan peningkatan prestasi dan pelayanan untuk tahun 2008, Kanwil Depag Riau misalnya, telah mengadakan raker Bidang Mapenda Islam yang diikuti sebanyak 100 orang peserta yang merupakan komponen pendidikan se Provinsi Riau yang terdiri dari Kasi Mapenda Kandepag Kabupaten dan Kota, Waspendais tingkat menengah dan dasar, Kepala RA, MI, MTs dan MA. Pembiayaan rapat kerja yang

${ }^{60}$ Basyuni, www.member.tripod.com

${ }^{61}$ Ibid.

${ }^{6}$ Ibid. berlangsung selama empat hari ini di bebankan pada DIPA Kanwil Depag Riau tahun anggaran 2008. Sedangkan materi dan pembahasan yang disampaikan diantaranya penyusuanan Rancangan Anggaran Pendapatan Belanja Madrasah (RAPBM), Akreditasi madrasah, sertifikasi guru, manajemen pengawasan berbasis kinerja dan manajemen praktis pengelolaan madrasah. ${ }^{63}$

Namun semua itu menurut penulis belum cukup untuk mengantarkan madrasah untuk mencapai sinar kesuksesan sebelum mewujudkan desentralisasi dalam pengelolaan madrasah secara optimal. Desentralisasi pendidikan madrasah dapat terlaksana dengan baik selain ditunjang oleh perangkat peraturan perundangan yang memadai, model pelaksanaan yang memberikan keleluasaan kewenangan dalam proses penetapan manajerial pendidikan, juga harus dengan dukungan kuat dari masyarakat

Dengan desentralisasi madrasah ini, diharapakan permasalahan madrasah bisa diminimalisir, bahkan, kalau bisa, dieliminir. Dan secara gradual, kualitas madrasahpun bisa ditingkatkan. Fuad Fahruddin menyebutkan beberapa keuntungan yang akan diperoleh madrasah apabila diotonomikan. Pertama, madrasah akan dianggap menjadi bagian yang tak terpisahkan dari sistem pendidikan nasional, dan dengan pengakuan tersebut madrasah akan mendapat perlakuan yang sama dengan sekolah lainnya, baik dalam hal alokasi dana maupun kebijakan pengembangan lainnya. Kedua, kepala madrasah dan guru akan dapat mengembangkan sumber daya yang ada dan mengembangkan program-program yang sesuai dengan kebutuhan masayarakat. Persoalan yang terkait dengan masayarakat dan sekolah akan dapat diselesaikan dengan segera karena struktur yang ada sudah sangat pendek (debirokratisasi). Ketiga, iklim akademik akan tumbuh dengan baik karena adanya kebebasan sekolah dalam mengembangkan program dan sumber belajar. Masyarakat bisa

63 Ghafar Usman, dalam: http//www.prakarsarakyat.org/artkel/news/artikel-php?aid=24981 
langsung memberikan saran, kritikan, masukan, serta usulan kepada kepala sekolah untuk kemajuan dan kebaikan sekolah. ${ }^{64}$

\section{Kesimpulan}

Berdasarkan analisis terhadap Undang-undang Sisdiknas dan Rencana Strategis Pendidikan Nasional 2004-2009, madrasah tertera sebagai bagian integral dari sistem pendidikan nasional. Dengan demikian, mereka punya hak dan kewajiban yang sama dengan sekolah. Dengan demikian penulis berkeyakinan, terealisirnya ide desentralisasi madrasah ini, madrasah akan mengalami perbaikan, sehingga cita-cita awal pendirian madrasah sebagai laboratorium untuk membina para siswa agar punya keimanan yang kuat secara vertikal dan berwawasan luas secara horizontal dapat terwujud.

\section{Bibliagrafi}

Alamsyah, Pembinaan Pendidikan Agama, (Jakarta: Depag RI, 1982)

A.Q. Azizi, Melawan Globalisasi Reinterpretasi Ajaran Islam Persiapan SDM dan Terciptanya Masyarakat Madani, (Yogyakarta: Pustaka Pajar, 2004)

Buchori, Muchtar, Agama dan Iptek (t.t: IKIP Muhamadiah, 1987)

Basyuni, Maftuh, dalam: http://www.member.tripod.com/urantiaIndonesia

Depag RI, Pendidikan Islam dan Pendidikan Nasional: Paradigma Baru (Jakarta: Dirjen Agama Islam, 2005)

, Desain Pengembangan Madrasab (Jakarta: Dirjen Binbaga, 2004)

Sejarah Madrasab: Pertumbuban, Dinamika, dan Perkembangannya di Indonesia, (Jakarta: Dirjen Agama Islam, 2004)

${ }^{64}$ Fachruddin, Madrasah dan Otonomi, hlm. 9
Darmuin, Prospek Pendidikan Islam di Indonesia: Suatu Telaah terbadap Pesantren dan Madrasah, (Jakarta: Novindo Pustaka Mandiri, 2004)

Daud, Afrianto, Mengusung Madrasah ke Diknas, dimuat di http:// Afriantodaud.com./2007/journal/item

Fadjar, Malik, Madrasah dan Tantangan Modernitas (Bandung: Mizan, 1998)

Fadjar, A. Malik, Holistika Pemikiran Pendidikan, Jakarta: Raja Grafindo, 2005)

Fakhruddin, Fuad, Madrasah dan Otonomi Daerab: Sebuah Telaab Awal dimuat dalam : http//www.Fuadfakhruddin.tripod.com /urintia-indonesia/htm

Fiske, Edward B. Desentralisasi of Education: Politics and Consensus (New Jersey: Engliwood Cliffs, 1979)

Gunawan, Ary. H. Kebijakan-kebijakan Pendidikan di Indonesia (Jakarta: Bina Aksara, 1986)

Kompas. Kamis, 05 Desember 2002, "Mulai Dihapus, Dikotomi Sekolah Umum-Madrasah"

Maksum, Sejarah Madrasah \& Perkembangannya, (Jakarta: Logos Wacana Ilmu, 1999)

Mattulada, Desentralisasi Pendidikan dalam Pelaksanaan Manajemen Pembangunan, (Jakarta: Pustaka Sinar Harapan, 1990)

Muhaimin, Wacana Pengembangan Pendidikan Islam, (Yogyakarta: Pustaka Pelajar, 2003) , Arah Baru Pengembangan Pendidikan Islam, Pemberdayaan, Pengembangan Kurikulum bingga Redefinisi Islamisasi Pengetahuan, (Bandung: Nuansa, 2003)

Matuhu, Memberdayakan Sistem Pendidikan Islam, (Jakarta: Logos Wacana Ilmu, 1999) 
Mulyasa, Manajemen Berbasis Sekolah, (Jakarta: Remaja Rosda Karya, 2002)

Muhaimin, Pemikiran Pendidikan Islam, (Bandung: Trigenda Karya, 1993)

Nizar, Samsul (Editor), Sejarab Pendidikan Islam: Menelusuri Jejak Sejarah Pendidikan Era Rasulullah Sampai Indonesia, Jakarta: Kencana, 2008)

Nata, Abuddin, Sejarah Pendidikan Islam, Jakarta: Raja Grafindo Persada, 2004)

Raharjo, Peran Masyarakat dalam Peningkatan Kualitas Madrasah, (Yogyakarta: Pustaka Pelajar, 2008)

Robin, dalam: Husni Rahim, Arah Baru Pendidikan Islam Indonesia, (Jakarta: Logos, 2001)

Saridjo, Marwan, Bunga Rampai Pendidikan Agama Islam, Jakarta: CV. Amisco, 1996)

Shaleh, Abdul Rachman, Madrasah dan Pendidikan Anak Bangsa Visi, Misi dan Aksi, (Jakarta: RajaGrafindo, 2005)

Steenbrink, Karel A., Pesantren, Madrasah, Sekolah, Jakarta : LP3ES, 1991)

Syafei, Silfia Nani, Membedah Akar Masalab Madrasah, dalam: http// silfiananisyafei.blogspot.com/2007

Sasongko, Agung dalam: Tempo, 24 November 2005, “ Pendidikan Agama Belum Capai Tujuan.".

Sudjana, Nana, Dasar-dasar Proses Belajar Mengajar, (Bandung: Sinar Baru Algasindo, 2004)

Sindhunata, Menggagas Paradigma Baru Pendidikan, Demokratisasi, Otonomi, Civil Society, Globalisasi (Yogyakarta: Kanisius, 2001)
Syukur, Fatah, Madrasah dan Pemberdayaan Peran Masyarakat, (Yogyakarta: Aditya Media, 2007)

Tilaar, Paradigma Baru Pendidikan Nasional (Jakarta: Rineka Cipta, 2004)

Thoha, Chabib dan Abdul Muth'i, PBM-PAI di Sekolah: Eksistensi dan Proses Belajar Mengajar Pendidikan Agama Islam, (Yogyakarta: Pustaka Pelajar, 1998)

Undang-Undang Nomor 20 Tahun 2003 tentang Sistem Pendidikan Nasional, (Bandung: Fokus Media, 2006)

Undang-Undang No. 22 Tahun 1999 Tentang Pemerintah Daerah, (Jakarta: CV. Novindo Pustaka Mandiri, 2001)

Umar, Yahya, dalam: http://bdg.Centeri.Net/Madrasah-Sekolah/ html

Undang-Undang No. 25 Tahun 1999 Tentang Pemerintah Daerah, (Jakarta: Biro Humas Departemen Dalam Negeri, 2000)

Usman, Ghafar, dalam: http//www.prakarsa-rakyat.org/artkel/news/ artikel-php?aid $=24981$

Yusroh, Yoyoh, dalam:http:// www.dutamasyarakat.com. /rubrik.php?id

Zuhairini, dkk, Sejarab Pendidikan Islam, (Jakarta: Bumi Aksara, 1997) 